\title{
Heat, Salinity, and Acidity, Commonly Upregulate A1aB1b Proglycinin in Soybean Embryonic Axes
}

\author{
Patricia Arce-Paredes ${ }^{1}$, Rosalva Mora-Escobedo ${ }^{1}$, Juan Pedro Luna-Arias ${ }^{2}$, \\ Guillermo Mendoza-Hernández ${ }^{3}$ and Oscar Rojas-Espinosa ${ }^{1}$ \\ ${ }^{1}$ Departamentos de Ingeniería Bioquímica e Inmunología, Escuela Nacional de Ciencias \\ Biológicas, Instituto Politécnico Nacional, México D.F., \\ 2Departamento de Biología Celular, Centro de Investigación y Estudios Avanzados, \\ Instituto Politécnico Nacional, México D.F., \\ ${ }^{3}$ Departamento de Bioquímica, Facultad de Medicina, \\ Universidad Nacional Autónoma de México, México D.F.
}

México

\section{Introduction}

All organisms respond to elevated temperatures and to chemical and physiological stress by increasing the synthesis of heat shock proteins. By definition, heat shock proteins (HSPs) are a group of functionally related proteins whose expression is increased when cells are exposed to elevated temperatures (De Maio, 1999). Brief exposure of cells to sub-lethal high temperature toughens the cells and provides protection from subsequent and even more severe temperature. In 1962, Ritossa reported that heat induced a characteristic pattern of puffing in the chromosomes of Drosophila. This discovery eventually led to the identification of the heat-shock proteins (HSPs) whose expression these puffs represented. Increased synthesis of specific proteins in Drosophila cells following heat shock was first reported in 1974 by Tissières et al. The regulation of heat shock gene expression in eukaryotes is largely mediated by the conserved heat shock transcription factors (HSFs). HSFs are present in a latent state under normal conditions. They are activated upon heat stress by induction of oligomerization and high-affinity binding to DNA and by exposure of domains for transcriptional activity (Wu, 1995). Experimental manipulation by molecular engineering of the heat response aims to select plant species resistant to hot weather, mainly in arid soils.

Stress factors other than heat also alter the cell physiology and induce stress responses comparable to that induced by thermal shock. Cellular energy depletion, extreme concentrations of ions, presence of uncommon osmolytes, rare gases, pollutants including many toxic substances, high or low temperatures, and drought, among others, all are stressing factors (Feder and Hofmann, 1999).

Beginning in the mid-1980's, researchers recognized that most stress-induced proteins, including HSPs, function as molecular chaperons. The chaperones are proteins that assist other proteins to fold, refold, travel to their place of residence (cytosol, organelle, 
membrane, extracellular space), and translocate across membranes. Molecular chaperones participate in a variety of physiological processes and are widespread in organisms, tissues, and cells. Chaperone failure will have an impact on one or more cellular functions, which may lead to disease or even to death (Macario and Macario, 2007).

The principal heat-shock proteins with chaperone activity belong to five conserved families: HSP60, HSP70, HSP90, HSP100, and the small HSPs (HSP10, HSP20-30, and HSP40) (Schlesinger, 1990, 1994; Li and Srivastava, 2004). Heat-shock proteins are components of the stress response of eukaryotic and prokaryotic cells subjected to a variety of adverse conditions. In plants, production of high levels of heat shock proteins can also be triggered by their exposure to different kinds of environmental stress conditions other than heat, including nitrogen deprivation, salinity in general and sodicity in particular, pollutants (heavy metals and pesticides), cold, and dryness, among others (Wang et al., 2003; Mahajan and Tuteja, 2005). Hence, HSPs are also known as stress proteins (Santoro, 2000). Hundreds of studies on plants of nutritious or economical importance subjected to a diversity of stress conditions, aimed to select resistant plant varieties, have been reported. Glycine max (LaFayette and Travis, 1990; Hsieh et al., 1992), Arabidopsis thaliana (Queitsch et al., 2000; Banti et al., 2008; Tonsor et al., 2008), Oryza sativa (Pareek, et al, 1995), Nicotiana tabacum (Usami et al., 1995), Triticum aestivum (Hendershot et al., 1992; Blumenthal, et al., 1998; Efeoglu and Terzioglu, 2007; Sancho et al., 2008), Zea mays (Cooper and Ho, 1983; Lund et al., 1998, Nieto-Sotelo et al., 2002), Prosopis chilensis (Ortíz el al., 1995; Ortíz and Cardemil. 2001), Pisum sativum (Lee et al., 1995), Lycopersicon esculentum (Polenta et al., 2007), Sorghum bicolor (Ougham and Stoddart 1986), Cicer arietinum (Bibi et al., 2009) and Phaseolus vulgaris (Nagesh-Babu and Devaraj, 2008) are within the many plants whose stress responses have been investigated.

Soybean subjected to thermal shock for brief periods respond by increasing the expression of certain proteins. The response is variable depending on several factors, mainly temperature, length of the shock, age of the crop at the time the thermal shock is applied, and source of the sample (embryonic axes, cotyledon, leaves, roots, etc.). Depending on these factors, several HSPs have been identified belonging to the five HSP families (Key et al., 1981; Mansfield and Key, 1987; Lin et al., 1984; Hsieh et al., 1992).

Stress response of soybean to high salinity has also been investigated; high salt concentrations have negative effects on growth, nodulation, seed quality and quantity, thus reducing the yield of soybean. To cope with salt stress, soybean has developed several resistance mechanisms, including: maintenance of ion homeostasis; adjustment in response to osmotic stress, restoration of osmotic balance, and other metabolic and structural adaptations (Phang et al., 2008).

As far as we know, the study of acidity and alkalinity as stressing factors on soybean has not been addressed. In this communication we report the experimentally-induced stress response of embryonic axes of soy to thermal shock $\left(40^{\circ} \mathrm{C}, 42^{\circ} \mathrm{C}\right)$, salinity $(200 \mathrm{mM} \mathrm{NaCl})$, and acidity $(\mathrm{pH} 5.5)$ in a comparative manner. Hot soils and soils with high salt concentration, as well as acid- or alkaline- soils, certainly constitute inappropriate substrates for the satisfactory growth of soybean and other plant species.

\section{Materials and methods}

\section{Chemicals}

Except otherwise indicated, chemical reagents were from Sigma/Aldrich Chemical Co. (Branch in Mexico). 


\section{Soybean seeds}

The variety Huasteca-100 of soybean (Glycine max) was used in this study; this variety was selected out of three other soybean varieties (Crystalline, UFV-1 and FT-0191) because of its good quality (Arce-Paredes et al, 2009) and because it is a prospect for high cultivation in certain regions in México (it is expected to cultivate up to 80 million square meters of land with soy Huasteca-100 by the year 2011). Soybean Huasteca-100 was contributed by Ing. Rafael Reza Alaman from Instituto Nacional de Investigaciones Forestales, Agrícolas y Pecuarias (INIFAP), campo experimental at Iguala, Guerrero, México, and it was a recent crop.

\section{Soybean minicrops}

Healthy soybean seeds were selected, decontaminated for $10 \mathrm{~min}$ in $1 \%$ hypochlorite in water, rinsed once with distilled water (DW), let to hydrate for $4 \mathrm{~h}$ with DW, and planted on moisten cotton beds at $28^{\circ} \mathrm{C}$. Moistening solutions depended on the experiment and were: 10 $\mathrm{mM}$ phosphate buffer, $\mathrm{pH} 7.0 ; 200 \mathrm{mM} \mathrm{NaCl}$ in $100 \mathrm{mM}$ phosphate buffer, or $10 \mathrm{mM}$ acetate buffer, pH 5.5.

\section{Heat shock}

Soybean seeds were grown on a cotton bed moistened with $10 \mathrm{mM}$ phosphate buffer, $\mathrm{pH}$ 7.0 , at $28^{\circ} \mathrm{C}$ for $48 \mathrm{~h}$ in the dark before they were subjected to thermal shock for $2 \mathrm{~h}$. At this time, germinated embryonic axes measured about $1.0 \mathrm{~cm}$ in length. Three lots were prepared and subjected to no heat-shock (lot 1, control), $40^{\circ} \mathrm{C}$ (lot 2), or $42^{\circ} \mathrm{C}$ (lot 3). Lots were then reincubated at $28^{\circ} \mathrm{C}$ for $4 \mathrm{~h}$. At this time, cultures were harvested and examined for changes in length, mass, and protein content profiles of embryo axes.

\section{Saline shock}

Lots of 50 soybean seeds were grown at $28^{\circ} \mathrm{C}$ on cotton beds moistened with $200 \mathrm{mM} \mathrm{NaCl}$ in $10 \mathrm{mM}$ phosphate buffer, $\mathrm{pH}$ 7.0. From previous results from heat-shocked soybean seeds, crops were harvested at $54 \mathrm{~h}$ of cultivation, time at which embryonic axes were excised, measured, weighted, and subjected to protein extraction.

\section{pH shock}

Lots of soybean seeds were grown at $28^{\circ} \mathrm{C}$ on cotton beds moistened with $10 \mathrm{mM}$ acetate buffer, $\mathrm{pH}$. 5.5. Based on previous results, crops were harvested at $54 \mathrm{~h}$ of cultivation and embryonic axes were collected, measured, weighted and subjected to protein extraction.

\section{Extract preparation}

At each harvesting time, embryonic axes were excised from germinated soybean seeds, measured, and weighted. Extracts were prepared from equal amounts (1.0 gram) of embryonic axes collected from each stress-treated soybean lot. Embryonic axes were cut into small $(2-3 \mathrm{~mm})$ pieces and then they were ground in a mortar with $5.0 \mathrm{ml}$ of $25 \mathrm{mM}$ Tris, 192 $\mathrm{mM}$ Glycine, $\mathrm{pH} 8.3$ solution in the presence of $1 \mathrm{mM}$ ethyl maleimide and $1 \mathrm{mM}$ phenylmethylsulfonyl fluoride (PMSF). After filtering trough Whatman No. 2 filter paper, extracts were centrifuged at 10,000 x g (Sorvall RC-5B, DuPont Inst., USA) for $15 \mathrm{~min}$ at $4^{\circ} \mathrm{C}$ and soluble extracts were sterilized through $0.2 \mu \mathrm{m}$ filters (Millipore), separated into $0.5 \mathrm{ml}$ aliquots, and stored frozen at $-20^{\circ} \mathrm{C}$ until used.

\section{Protein contents}

The amount of protein in each extract was determined by a micro-adaptation to the Lowry's method (Lowry et al., 1951). Assay was carried out in ELISA plates containing $200 \mu \mathrm{l}$ of 
alkaline reagent per well. The alkaline reagent consisted of $0.2 \%$ sodium-potassium tartrate, $0.1 \%$ cupric sulfate and $2 \%$ sodium carbonate in $0.1 \mathrm{~N}$ sodium hydroxide. Ten microliters of serially diluted samples or protein standard (BSA, $1 \mathrm{mg}$ per $\mathrm{ml}$ ) were added per well. The plates were thoroughly shaken and then left undisturbed for $15 \mathrm{~min}$. Then, $10 \mu \mathrm{l}$ of FolinCiocalteau's reagent were added per well. Well-contents were individually homogenized by pipetting and plates were left undisturbed for $30 \mathrm{~min}$ at room temperature. Finally, absorbance at $600 \mathrm{~nm}$ was measured in an ELISA-reader (Labsystems multiscan Plus, Finland).

\section{Protein precipitation}

One $\mathrm{ml}$ of soluble extracted protein was mixed with $8 \mathrm{ml}$ of $100 \%$ ice-cold acetone and $1 \mathrm{ml}$ of $100 \%$ TCA. The mixture was kept at $-20^{\circ} \mathrm{C}$ for $1 \mathrm{~h}$ and then centrifuged at $18,000 \times \mathrm{g}$ (Sorvall, RC-5B, DuPont Instr., USA) for $15 \mathrm{~min}$ at $4^{\circ} \mathrm{C}$. Supernatant was discarded and the precipitate was washed with $1 \mathrm{ml}$ of ice-cold acetone and recovered by centrifugation as above. Finally, the precipitate was dissolved in lysis buffer as described below.

\section{Protein solubilisation}

Proteins were dissolved in 2-D lysis buffer (30 mM Tris- $\mathrm{HCl}, \mathrm{pH} 8.8$, containing $7 \mathrm{M}$ urea, 2 $\mathrm{M}$ thiourea and 4\% CHAPS) and incubated at room temperature for $30 \mathrm{~min}$ on a shaker. Protein solutions were centrifuged for $30 \mathrm{~min}$ at 16,000 x g (Sorvall, RC-5B, DuPont Instr., USA) at room temperature, supernatants were collected and their protein content were measured using the micro-Lowry method already described.

\section{CyDye labeling and Two dimensional differential in gel electrophoresis (2D-DIGE)}

To label proteins, $30 \mu \mathrm{g}$ of each protein samples were incubated with $0.7 \mu \mathrm{l}$ of CyDye solutions (Cy2, Cy3 or Cy5) diluted 1:5 in dimethyl formamide (DMF) from $1 \mathrm{nmol} / \mu \mathrm{l}$ stock, (GE Healthcare, Piscataway, NJ) at $4^{\circ} \mathrm{C}$ for $30 \mathrm{~min}$. Labeling was stopped by adding $0.7 \mu \mathrm{l}$ of 10 $\mathrm{mM}$ L-Lysine and incubating at $4^{\circ} \mathrm{C}$ for $15 \mathrm{~min}$. Then, labeled samples were mixed together, and equal volume of 2X 2-D sample buffer (8 M urea, 4\% CHAPS, $20 \mathrm{mg} / \mathrm{ml}$ dithiotreitol (DTT), 2\% pharmalytes and a trace amount of bromophenol blue) and $100 \mu \mathrm{l}$ of destreak solution (GE Healthcare) were added. Total sample volumes were adjusted to $260 \mu \mathrm{l}$ by adding Rehydration buffer (7 M urea, $2 \mathrm{M}$ thiourea, 4\% CHAPS, $20 \mathrm{mg} / \mathrm{ml}$ DTT, $1 \%$ pharmalytes and a trace amount of bromophenol blue). Samples were incubated at room temperature for $10 \mathrm{~min}$ on a shaker and centrifuged for $10 \mathrm{~min}$ at 16,000 x g (Sorvall, RC-5B, DuPont Instr., USA). Finally, supernatants were loaded onto $13 \mathrm{~cm}$ IPG strip holder (GE Healthcare).

\section{Isoelectrofocusing (IEF) and SDS-PAGE}

Thirteen cm IPG strips (pH 3-10) were put on the loaded samples and $1 \mathrm{ml}$ of mineral oil was added on top of the strip. Isoelectrofocusing experiments (IEF) were run following the protocol provided by the manufacturer (GE Healthcare). Upon completion of IEF, strips were equilibrated in buffer 1 (50 mM Tris- $\mathrm{HCl}, \mathrm{pH} 8.8$, containing $6 \mathrm{M}$ urea, 30\% glycerol, $2 \%$ sodium dodecyl sulfate (SDS), a trace amount of bromophenol blue and $10 \mathrm{mg} / \mathrm{ml}$ DTT) for 15 minutes and then in buffer $2(50 \mathrm{mM}$ Tris- $\mathrm{HCl}, \mathrm{pH} 8.8$, containing $6 \mathrm{M}$ urea, $30 \%$ glycerol, $2 \%$ SDS, trace amount of bromophenol blue and $45 \mathrm{mg} / \mathrm{ml} \mathrm{DTT)} \mathrm{for} 10 \mathrm{~min}$ with gentle agitation. IPG strips were then rinsed once in the SDS-gel running buffer, transferred to a $10.5 \%$ SDSgel prepared using low fluorescent glass plates) and sealed with $0.5 \%(\mathrm{w} / \mathrm{v})$ agarose solution (in SDS-gel running buffer). Electrophoresis was performed at room temperature until dye fronts run out of the gels. 


\section{Image scan and data analysis}

Upon completion of electrophoresis, gels were scanned using Typhoon TRIO (Amersham BioSciences) following the manufacturer's protocol. The scanned images were then processed by Image Quant software (version 5.0, Amersham BioScience). The quantitative analysis of protein spots was performed using DeCyder software (version 6.5).

\section{Preparative gel}

Unlabeled proteins $(600-700 \mu \mathrm{g})$ were run in analytical gels and stained with Deep Purple total protein stain (GE Health care). Then, gels were scanned and images were processed by DeCyder software to generate a pick list.

\section{Protein identification by Mass Spectrometry}

\section{Spot picking and Trypsin digestion}

Spots of interest were picked up by Ettan Spot Picker (Amersham BioSciences) based on the in-gel analysis and spot picking design by DeCyder software. The gel spots were washed a few times then digested in-gel with modified porcine trypsin protease (Trypsin Gold, Promega). Digested tryptic peptides were desalted by Zip-tip C18 spin columns (Millipore) and peptides were eluted from the Zip-tip columns with $0.5 \mu \mathrm{l}$ of matrix solution $(5 \mathrm{mg} / \mathrm{ml}$ a-cyano-4-hydroxycinnamic acid in 50\% acetonitrile, $0.1 \%$ trifluoroacetic acid, $25 \mathrm{mM}$ ammonium bicarbonate), and spotted on a MALDI plate (model ABI 01-192-6-AB).

\section{Mass Spectrometry Analysis}

MALDI-TOF MS and TOF/TOF tandem MS/MS were performed on an ABI 4700 mass spectrometer (Applied Biosystems, Framingham, MA). MALDI-TOF mass spectra were acquired in reflectron positive ion mode, averaging 4000 laser shots per spectrum. TOF/TOF tandem MS fragmentation spectra were acquired for each sample, averaging 4000 laser shots per fragmentation spectrum on each of the 10 most abundant ions present in each sample (excluding trypsin autolytic peptides and other known background ions).

\section{Database search}

Both of the resulting peptide mass and the associated fragmentation spectra were submitted to GPS Explorer workstation equipped with MASCOT search engine (Matrix science) to search the database of National Center for Biotechnology Information non-redundant (NCBInr). Searches were performed without constraining protein molecular weight or isoelectric point, with variable carbamido methylation of cysteine and oxidation of methionine residues, and with one missed cleavage also allowed in the search parameters. Candidates with either protein score C.I.\% or Ion C.I.\% greater than 95 were considered significant.

\section{Results}

Protein profiles of soybean embryonic axes grown in different stress conditions obtained by two dimensional differential in gel electrophoresis (2D-DIGE)

Proteins extracted from the embryonic axes of soybean subjected to nil (control lot 1), $\mathrm{HS} 40^{\circ} \mathrm{C}$ (lot 2$), \mathrm{HS}_{2}{ }^{\circ} \mathrm{C}$ (lot 3), acid shock (AS) at pH 5.5 (lot 4), or saline shock (SS) at 200 $\mathrm{mM} \mathrm{NaCl}$ (lot 5) were fractionated by two-dimensional differential gel electrophoresis (2DDIGE) as mentioned in Materials and Methods. In each case, matching of protein spots across the gels allowed us to calculate the relative volume of each spot (RV) as the ratio: 
volume of a particular spot/ volume of all spots detected in the gel. Those protein spots that showed an increase or a decrease in their RV of at least 1.5 times in relation to control sample (lot 1) were qualified as stress proteins (SPs) or HSPs. Under this criterion, we detected $35 \mathrm{HSPs}$ in lot $2\left(\mathrm{HS} 40^{\circ} \mathrm{C}\right), 15 \mathrm{HSPs}$ in lot 3 (HS42 $\left.{ }^{\circ} \mathrm{C}\right), 31$ ASPs in lot 4 (pH 5.5), and 29 SSPs in lot $5(\mathrm{NaCl} 200 \mathrm{mM})$. In addition, 11 protein spots showed a diminution in lot $\mathrm{HS} 42^{\circ} \mathrm{C}$. In general, most stressing conditions induced changes in the same proteins. In other words, same proteins were affected by the several stressing factors, with some exceptions.

\section{D-DIGE maps}

Figure 1 shows the 2D-DIGE map of proteins extracted for embryonic axis of soybean grown under normal conditions (Control lot 1 , in green), and the protein map for embryonic axes of soybean subjected to $\mathrm{HS}$ of $40^{\circ} \mathrm{C}$ for $2 \mathrm{~h}$ (lot 2, in red). Over 2000 protein spots were detected in all lots. Thermal shock (HS $40^{\circ} \mathrm{C} / 2 \mathrm{~h}$ ) induced the over-expression of 35 proteins, the largest number of up-regulated proteins in the experiment. Those proteins over expressed more than 1.5 fold in relation to the control lot appear encircled and orderly numbered from top to bottom.

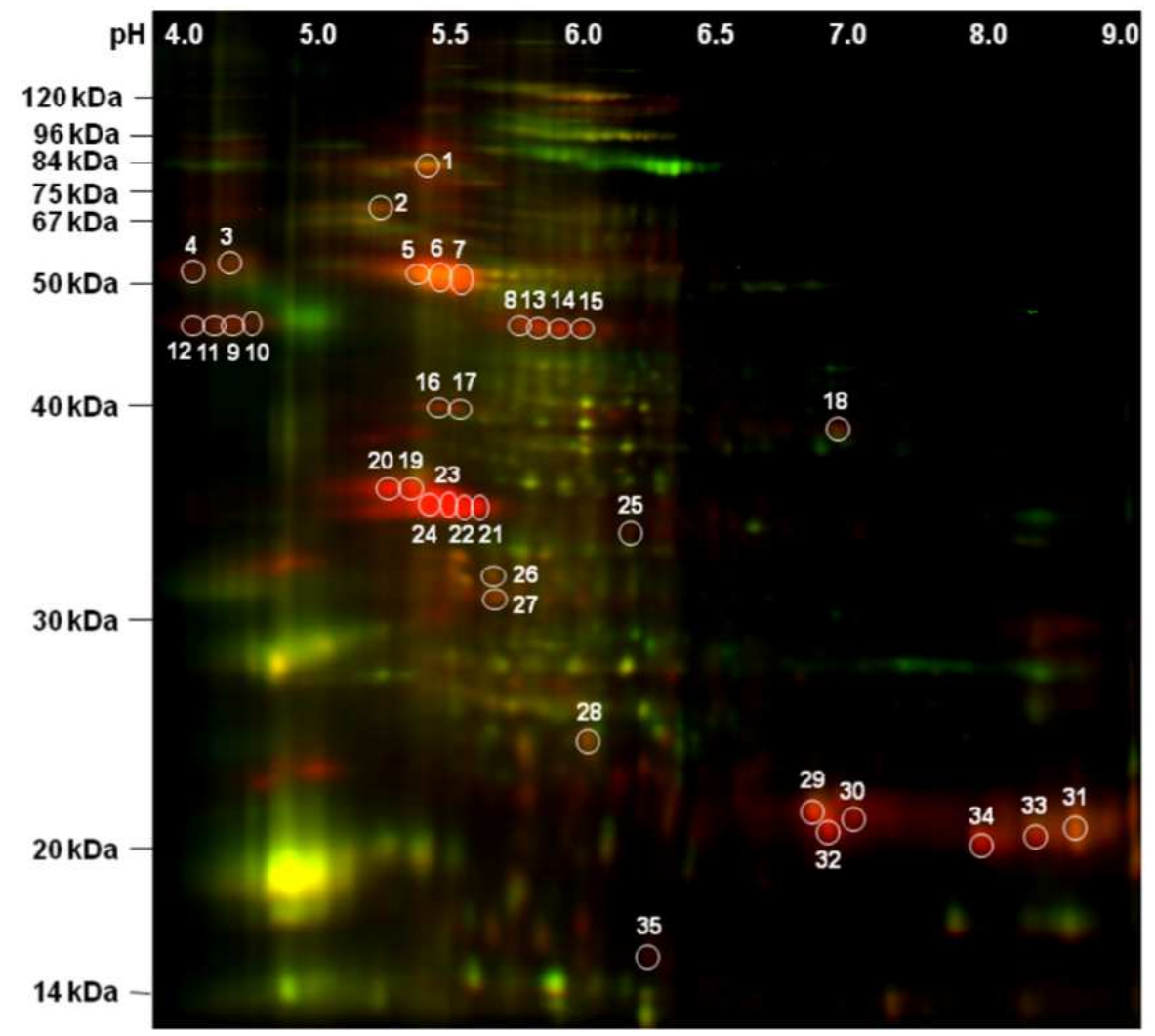

Fig. 1. 2D-DIGE expression map of the proteins extracted from embryonic axes of intact soybean (green) and soybean subjected to thermal shock at $40^{\circ} \mathrm{C}$ for $2 \mathrm{~h}$ (red). Thirty-five proteins (encircled and numbered) were over- expressed in relation to the control lot sample. 
Figure 2 shows the 2D-DIGE map of proteins extracted from the embryonic axes of soybean subjected to thermal shock at $42{ }^{\circ} \mathrm{C}$ for $2 \mathrm{~h}$ (lot 3). In the image, proteins that were overexpressed (15) are encircled and numbered, proteins that were under expressed (11) are only encircled but not numbered, and proteins whose expression was not modified are not pointed at. All protein spots retained their number given in relation to spot proteins in lot 2.

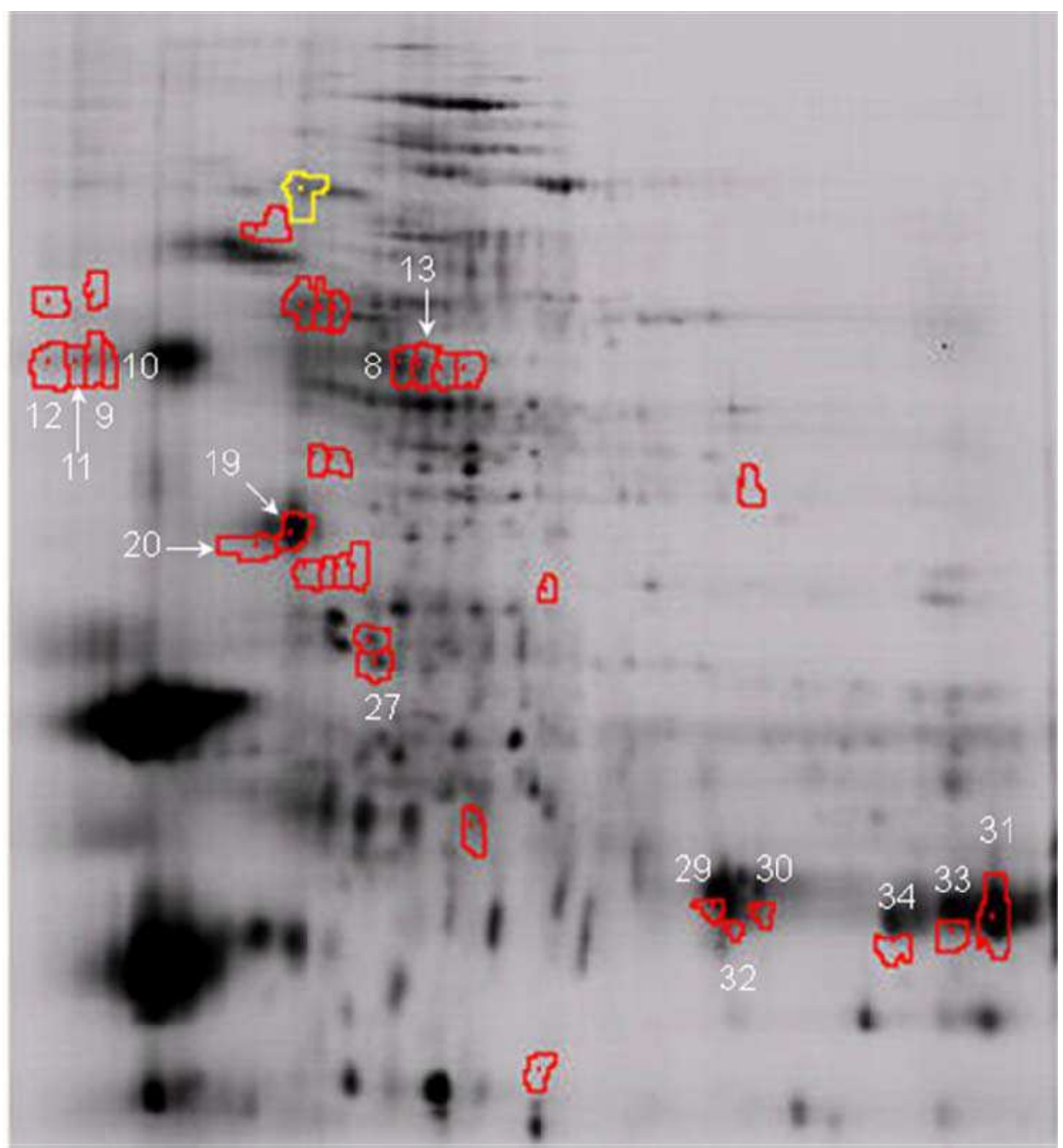

Fig. 2. 2D-DIGE map of the proteins extracted from the embryonic axes of soybean subjected at $42^{\circ} \mathrm{C}$ for $2 \mathrm{~h}$. Fifteen proteins were over-expressed (encircled and numbered), 11 proteins were under-expressed (encircled but not numbered) and 9 proteins were not modified (not pointed at). Numbers given in reference to the protein map of soybean subjected to $40^{\circ} \mathrm{C} / 2$ $\mathrm{h}$ (lot 2). Arrows identify single spots within a tight group of spots. Yellow circle marks a specific spot not particularly relevant for this study. 
2D-DIGE map of the proteins extracted from embryonic axes of soybean subjected to $\mathrm{pH} 5.5$ is shown in Figure 3. Compared with the map for soybean subjected to thermal shock at $40^{\circ} \mathrm{C}$ (lot 2), 31 proteins were over-expressed (encircled and numbered spots). Protein spots are numbered in relation to spot proteins in lot 2.

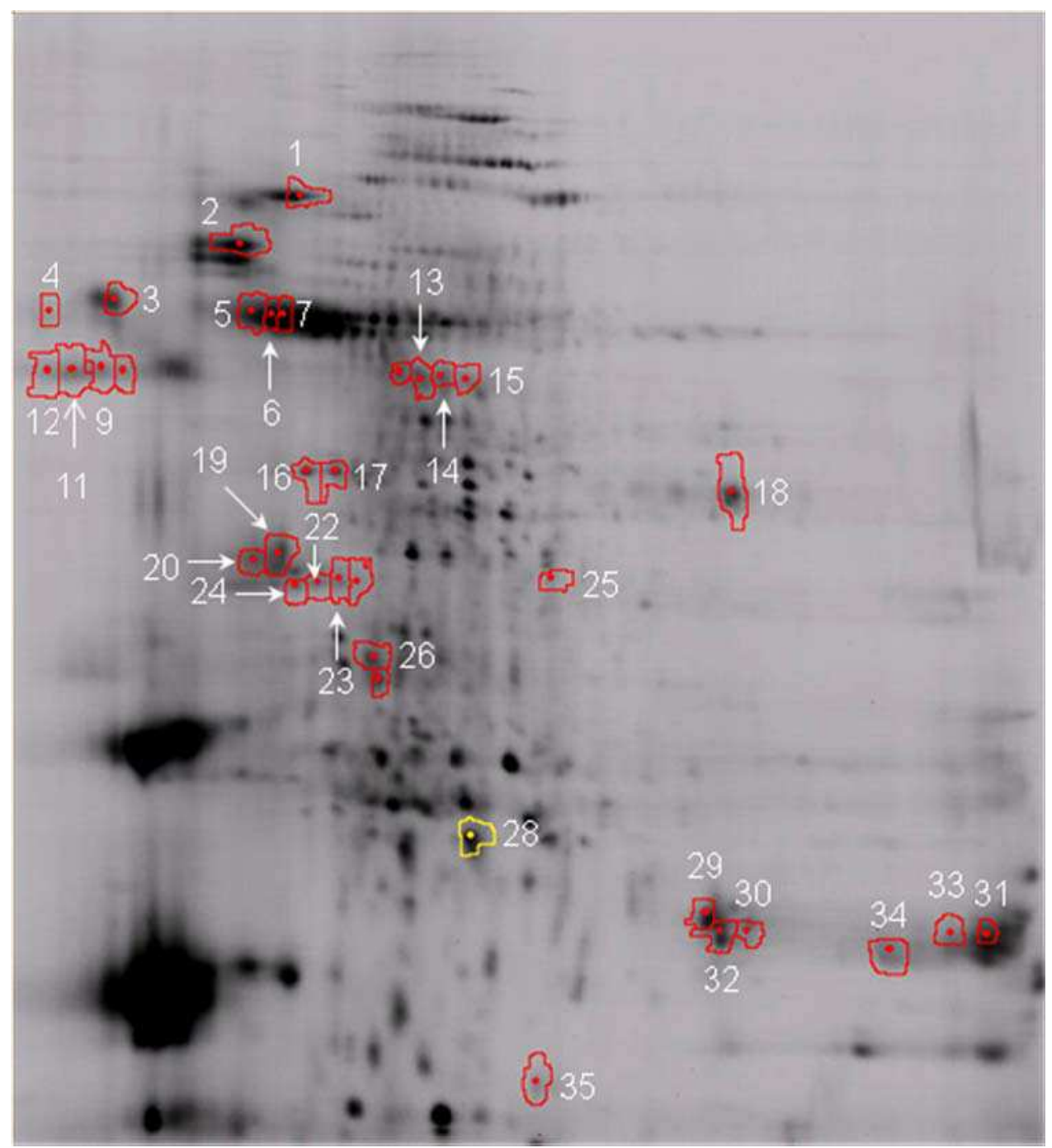

Fig. 3. 2D-DIGE image of proteins extracted from the embryonic axes of soybean grown at pH 5.5. Thirty-one proteins were over-expressed (encircled and numbered). Arrows identify single spots within a tight group of spots. Yellow circle marks a specific spot not particularly relevant for this study. 
2D-DIGE spot map of proteins extracted from embryonic axes of soybean grown in the presence of $200 \mathrm{mM} \mathrm{NaCl}$ is shown in Figure 4. Twenty-nine proteins behaved as HSPs by increasing their expression beyond 1.5 fold (spots encircled and numbered) in relation to control sample.

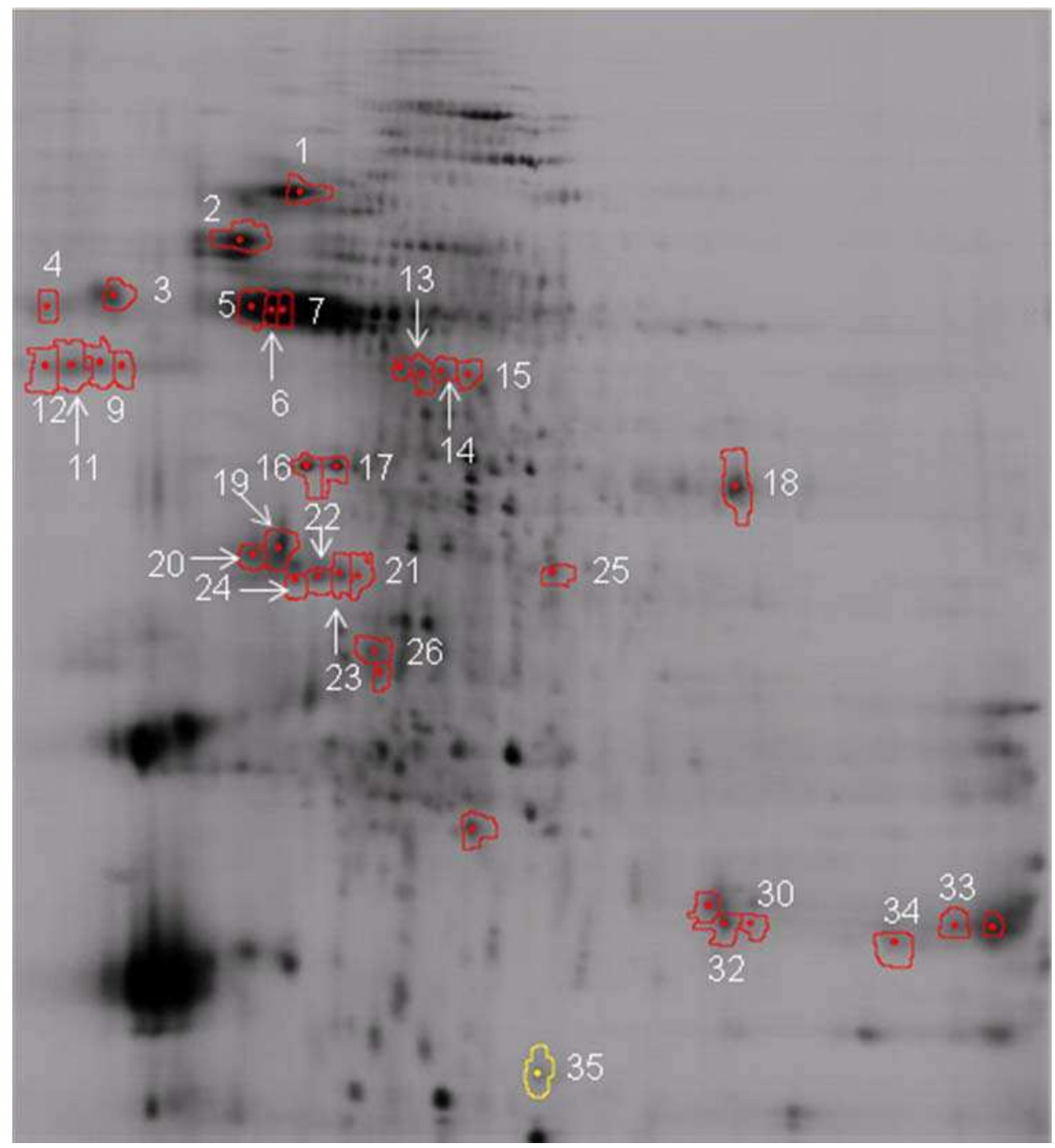

Fig. 4. 2D-DIGE spot map of proteins of embryonic axes of soybean cultured in the presence of $200 \mathrm{mM} \mathrm{NaCl}$. Twenty-nine proteins were over expressed (encircled and numbered). Arrows identify single spots within a tight group of spots. Yellow circle marks a specific spot not particularly relevant for this study. 
The relative volume ratio (stressing factor/control) of the proteins whose expression was modified in response to the several stressing factors tested is shown in Table 1 . The strongest stressing, non-lethal factor was thermal shock of $40^{\circ} \mathrm{C}$ for $2 \mathrm{~h}$. This stressing factor

\begin{tabular}{|c|c|c|c|c|}
\hline $\begin{array}{l}\text { Protein } \\
\text { ID }\end{array}$ & $\begin{array}{c}\mathrm{HS} 40^{\circ} \mathrm{C} / \text { Control } \\
\text { Volume Ratio }\end{array}$ & $\begin{array}{c}\mathrm{HS} 42^{\circ} \mathrm{C} / \text { Control } \\
\text { Volume Ratio }\end{array}$ & $\begin{array}{l}\mathrm{pH} \text { 5.5/Control } \\
\text { Volume Ratio }\end{array}$ & $\begin{array}{c}200 \mathrm{mM} / \text { Control } \\
\text { Volume Ratio }\end{array}$ \\
\hline 1 & 2,79 & $-1,63$ & 1,63 & 2,36 \\
\hline 2 & 2,65 & $-1,99$ & 2,58 & 3,00 \\
\hline 3 & 2,98 & $-5,84$ & 2,33 & 2,33 \\
\hline 4 & 2,17 & $-1,84$ & 1,90 & 3,53 \\
\hline 5 & 5,21 & $-2,03$ & 2,54 & 5,63 \\
\hline 6 & 5,99 & $-1,97$ & 2,51 & 4,76 \\
\hline 7 & 8,07 & $-2,20$ & 2,73 & 5,06 \\
\hline 8 & 6,99 & 3,59 & 1,04 & 1,22 \\
\hline 9 & 4,68 & 1,68 & 2,18 & 2,55 \\
\hline 10 & 4,28 & 1,80 & 1,39 & 1,34 \\
\hline 11 & 4,75 & 1,82 & 3,77 & 4,63 \\
\hline 12 & 4,00 & 1,73 & 3,40 & 3,71 \\
\hline 13 & 5,34 & 2,89 & 2,10 & 1,79 \\
\hline 14 & 4,95 & 1,08 & 2,18 & 2,17 \\
\hline 15 & 5,50 & $-1,35$ & 1,63 & 1,85 \\
\hline 16 & 7,24 & 1,31 & 3,48 & 6,00 \\
\hline 17 & 3,41 & $-1,07$ & 1,66 & 2,61 \\
\hline 18 & 1,50 & $-4,68$ & 2,31 & 2,89 \\
\hline 19 & 5,56 & 3,18 & 1,67 & 2,14 \\
\hline 20 & 16,11 & 2,18 & 2,05 & 3,25 \\
\hline 21 & 29,55 & $-1,59$ & 1,34 & 2,10 \\
\hline$\underline{22}$ & $\underline{87,07}$ & 1,01 & $\underline{15,48}$ & 24,32 \\
\hline$\overline{23}$ & $\overline{50.00}$ & $-1,26$ & $\overline{2,51}$ & $\overline{4,48}$ \\
\hline$\underline{24}$ & 78,67 & $-1,06$ & $\underline{10,07}$ & $\underline{12,63}$ \\
\hline$\overline{25}$ & $\overline{1,90}$ & $-2,47$ & $\overline{2,18}$ & $\overline{4,05}$ \\
\hline 26 & 2,07 & 1,44 & 1,51 & 1,64 \\
\hline 27 & 2,73 & 1,94 & 1,48 & 1,21 \\
\hline 28 & 1,97 & $-1,50$ & 1,87 & 1,05 \\
\hline 29 & 7,55 & 3,30 & 1,93 & 1,23 \\
\hline 30 & 10,40 & 4,52 & 3,32 & 2,32 \\
\hline 31 & 3,70 & 4,33 & 1,88 & 1,46 \\
\hline 32 & 15,86 & 4,43 & 3,57 & 2,10 \\
\hline 33 & 6,78 & 3,17 & 1,72 & 1,56 \\
\hline 34 & 13,02 & 2,83 & 2,83 & 1,98 \\
\hline 35 & 3,42 & 1,01 & 3,01 & 2,94 \\
\hline Up-regulated & 35 & 15 & 31 & 29 \\
\hline Down-regulated & 0 & 11 & 0 & 0 \\
\hline Non affected & 0 & 9 & 4 & 6 \\
\hline
\end{tabular}

Table 1. Relative volume ratios (stress factor/ control) of 2D-DIGE spot proteins of soybean subjected to diverse stressing conditions. 
induced the over-expression of 35 proteins that in the 2D-DIGE map are identified from top to bottom with a progressive identification (ID) number (spots ID-1 to ID-35). A similar effect was observed when $\mathrm{pH} 5.5$ and $200 \mathrm{mM} \mathrm{NaCl}$ were the stressing factors: 31 proteins were over-expressed at $\mathrm{pH} 5.5$ and 29 proteins were over-expressed at $200 \mathrm{mM} \mathrm{NaCl}$. The most deleterious effect on the germination of soybean was observed when the stressing factor was thermal shock of $42^{\circ} \mathrm{C}$ for $2 \mathrm{~h}$. Under this condition, of the 35 proteins identified, 11 were down-regulated, 15 proteins were over-expressed and 9 proteins were unaffected.

The most interesting observation that comes out from the results shown in Table 1 is that 2 protein spots, ID-22 and ID-24, maximally increased their expression under all of the stressing situations tested, excepting the heat shock at $42^{\circ} \mathrm{C}$ for $2 \mathrm{~h}$, which was the most lethal stressing factor in this study.

\section{Volume graphs}

The volume graphs for spot proteins ID-22 and ID-24 appear in Figures 5 and 6, respectively. The images, obtained with the DeCyder Differential Analysis Software version 6.5, show the spot number and position in the gel, the calculated relative volume, the peak height, and the area of each spot. Protein ID-22, increased 87.07 times at $40^{\circ} \mathrm{C}$ for $2 \mathrm{~h}$ in relation to the same protein in the control lot (lot-1) (Figure 5), while protein ID-24 increased 78.67 times at $40^{\circ} \mathrm{C}$ for $2 \mathrm{~h}$ over the same spot in the control lot (Figure 6).

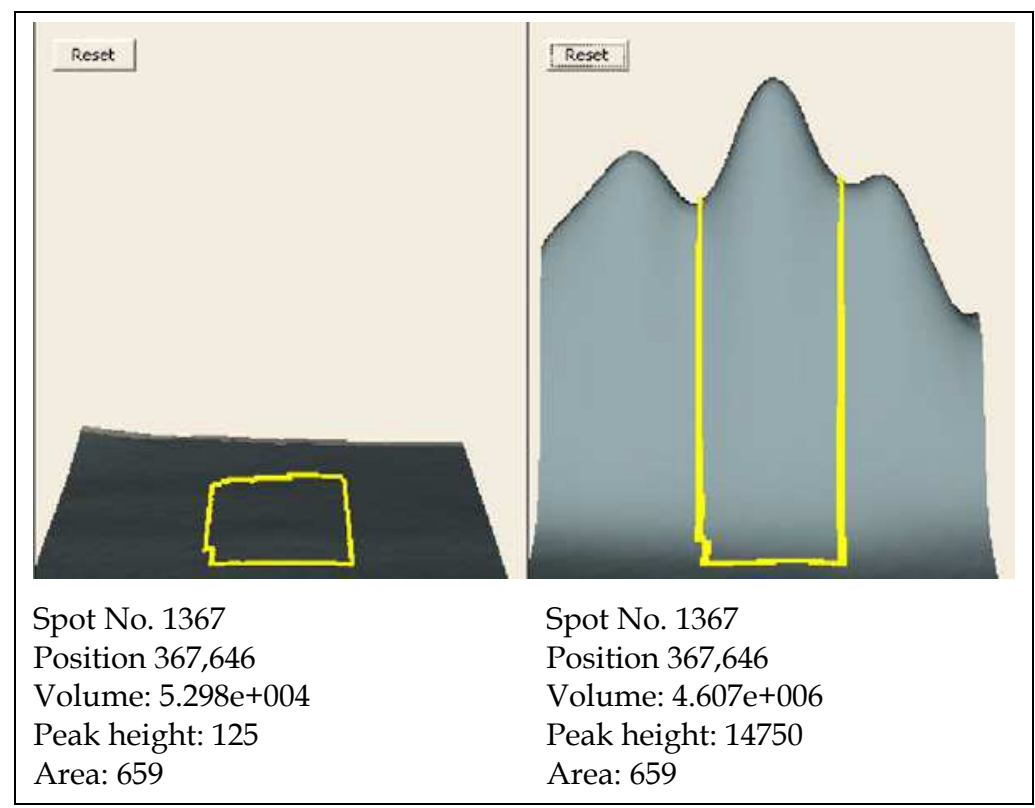

Fig. 5. Relative volume graph of 2D-DIGE spot ID-22 from soybean subjected to thermal shock of $40^{\circ} \mathrm{C}$ for $2 \mathrm{~h}$ (right panel) compared to the relative volume of the same spot in the control, intact lot (left panel). 


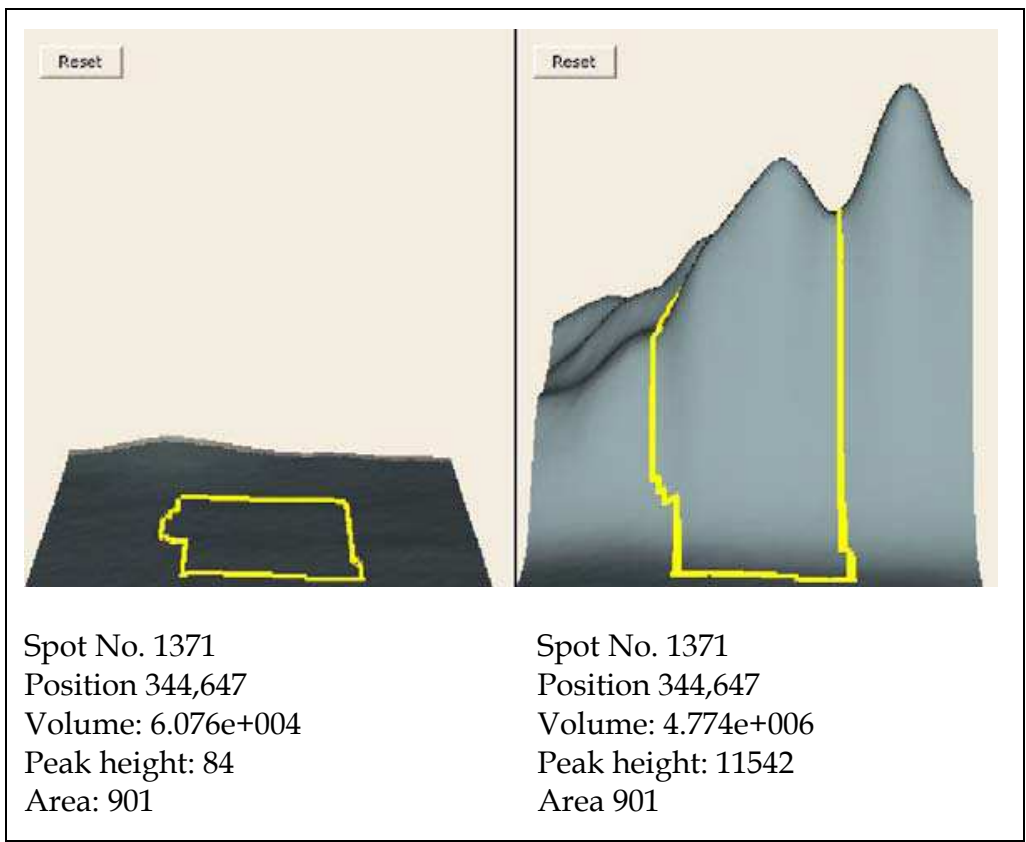

Fig. 6. Relative volume graph of 2D-DIGE spot ID-24 from soybean subjected to thermal shock of $40^{\circ} \mathrm{C}$ for $2 \mathrm{~h}$ (right panel) compared to the relative volume of the same spot in the control, intact lot (left panel)

\section{Protein identification by peptide mass fingerprint from two-dimensional gels}

To identify the ID-22 and ID-24 spot proteins, we proceeded to analyze them by MALDITOF MS and TOF/TOF tandem MS/MS as described in Material and Methods.

The mass spectrum (MS) obtained for tryptic peptides eluted from 2-D gel spot ID 22 is shown in Figure 7. After baseline correction, background subtraction and peak deisotoping, 10 high-scored ions were submitted to Mascot. Four of the submitted ions matched to theoretical tryptic peptides from chain C, crystal structure of soybean proglycinin A1aB1b homotrimer (Accession No. gi|15988119). The sequences of these peptides are given together with the mass of monoisotopic, single charged ions. The peptide with the highest ion score (IS 42, CI $96.051 \%$ ) appears within a rectangle. The mass spectrum MS/MS for this ion is shown in Figure 8.

Figure 9 shows the mass spectrum obtained for tryptic peptides eluted from 2-D gel spot ID24. The 10 high-scored ions were submitted to Mascot server. Four of the submitted ions matched to theoretical tryptic peptides from chain C, crystal structure of Soybean proglycinin A1aB1b homotrimer (gi|15988119). The sequences of these peptides are given together with the mass of monoisotopic, single charged ions. The peptide with the highest ion score $(42$, CI $96.051 \%)$ appears within a rectangle. The mass spectrum MS/MS for this ion is shown in Figure 10. 


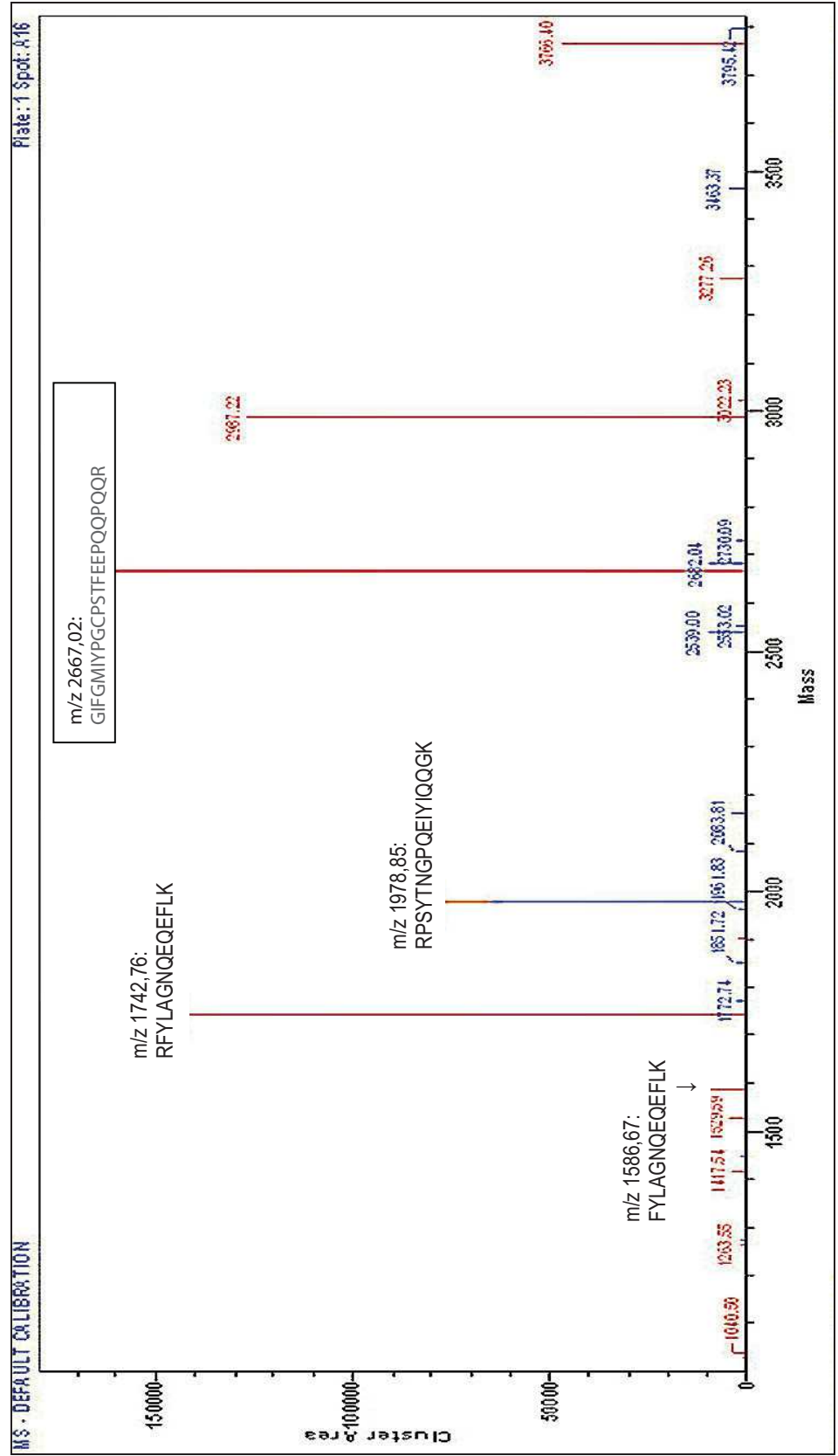

Fig. 7. Mass spectrum (MS) of tryptic peptides eluted from 2D-DIGE spot 22 . The $\mathrm{m} / \mathrm{z}$ value and sequence for each peptide is shown in the graph. The peptide with the highest ion score $(42$, CI $96.051 \%)$ appears within a rectangle. 


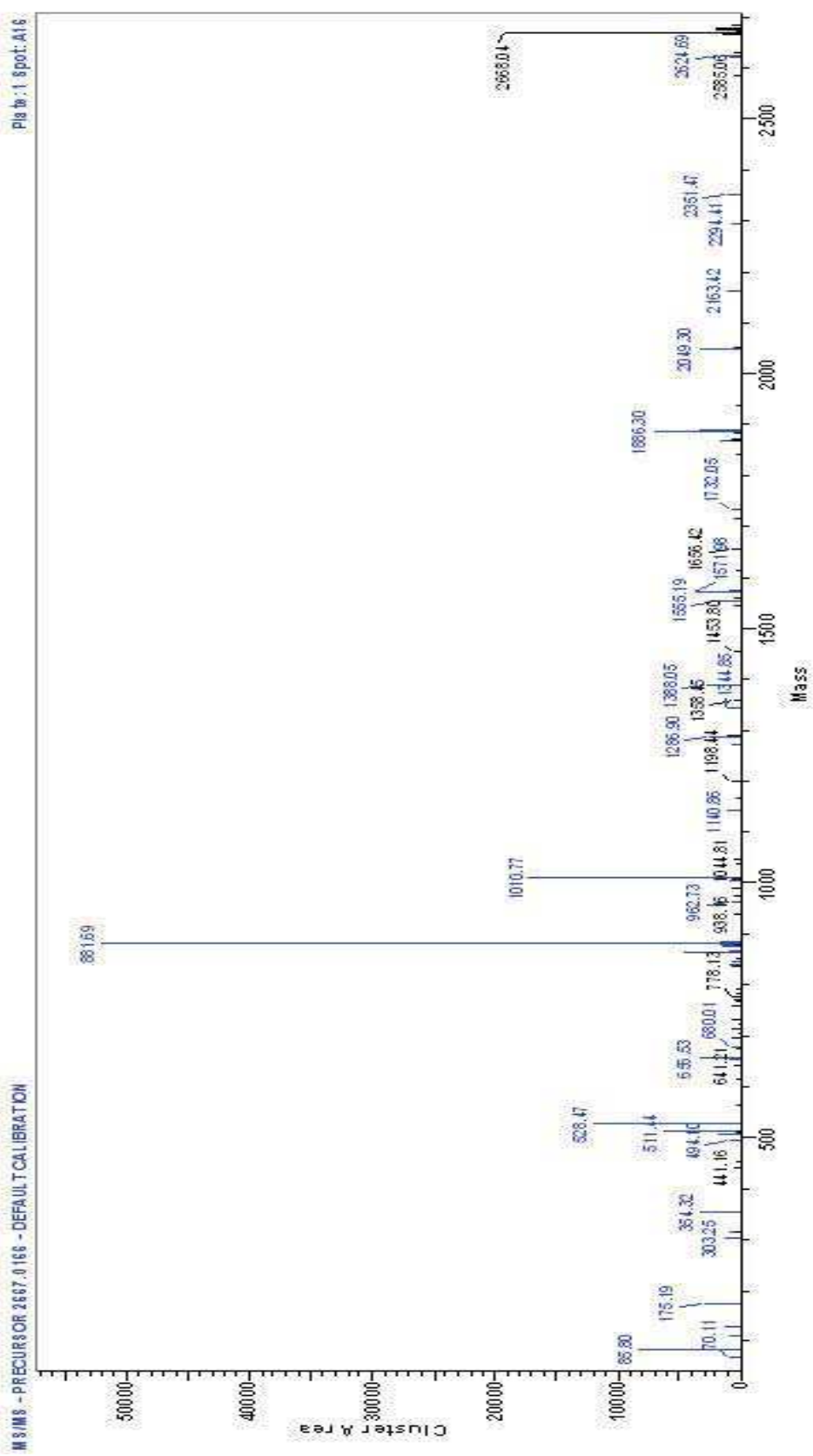

Fig. 8. MS/MS spectrum of peptide m/z 2667.02 (GIFGMIYPGCPSTFEEPQQPQQR) from protein spot ID 22. Sequences of these peptide ions fit within the sequence of peptide $\mathrm{m} / \mathrm{z}$ 2667.02 


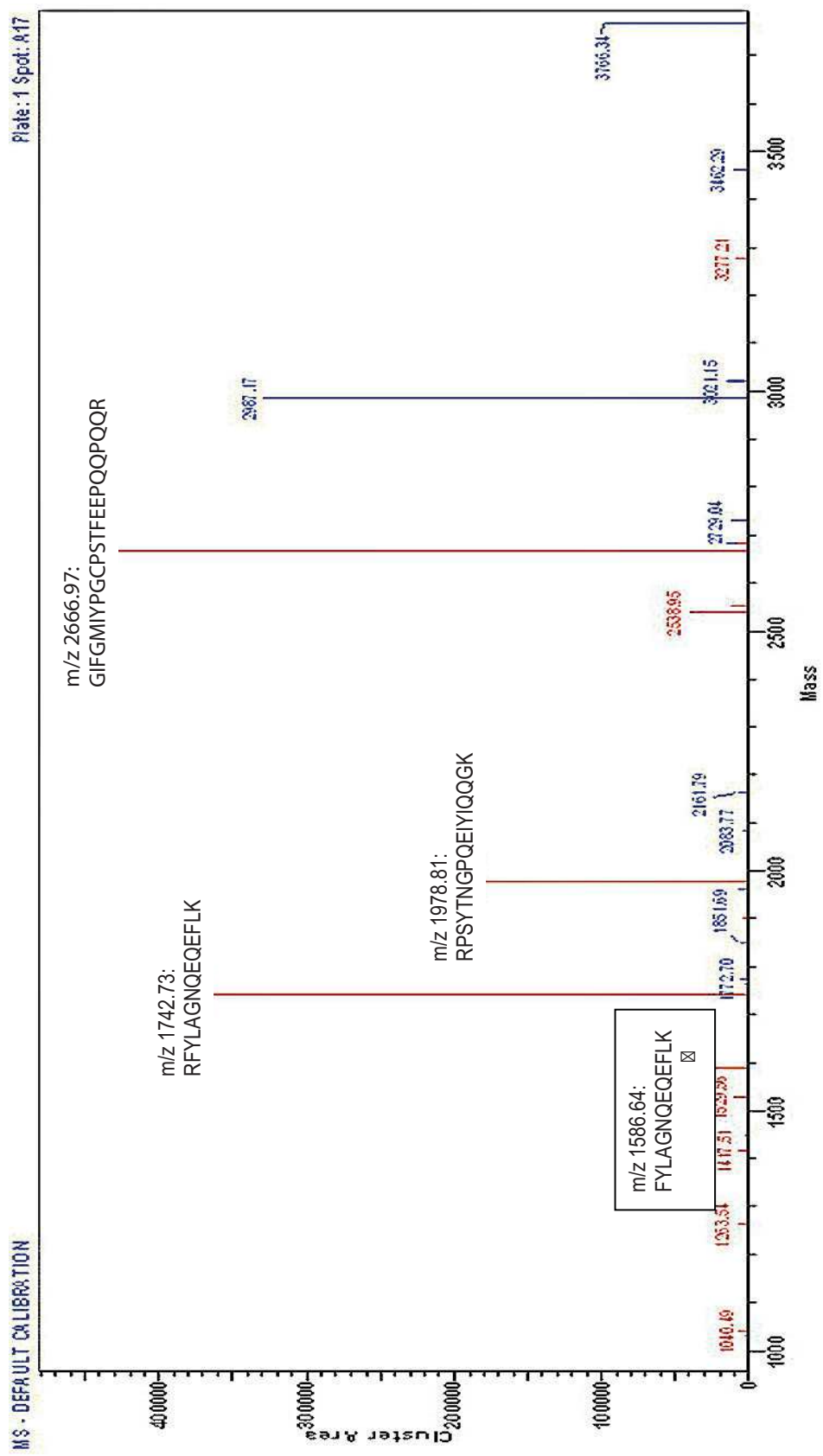

Fig. 9. Mass spectrum (MS) of tryptic peptides eluted from 2D-DIGE spot 24 . The $\mathrm{m} / \mathrm{z}$ value and sequence for each peptide is shown in the graph. The peptide with the highest ion score $(42$, CI $96.051 \%)$ appears within the rectangle. 


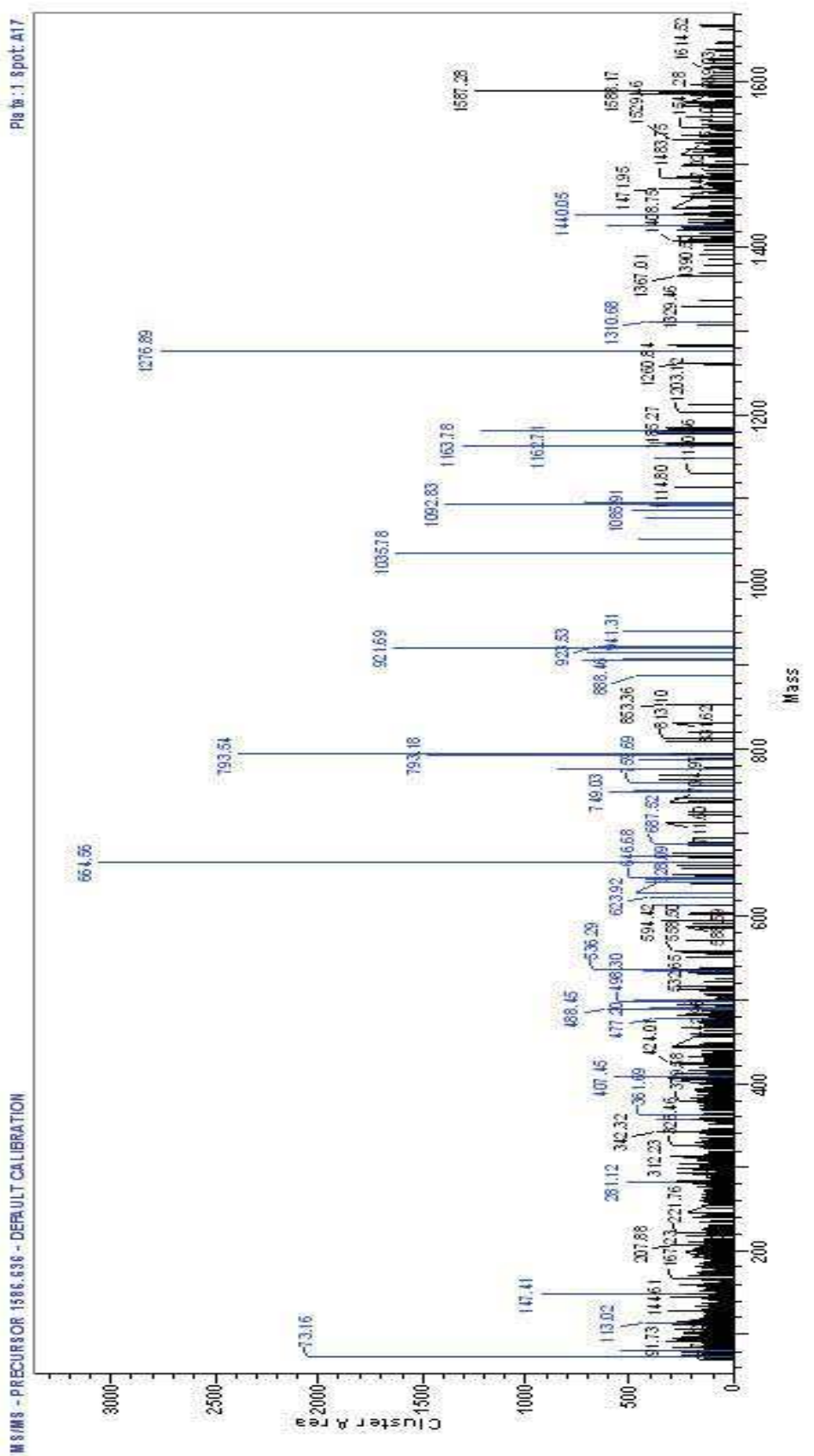

Fig. 10. MS/MS spectrum of peptide m/z 1586.64 (FYLAGNQEQEFLK) from protein spot ID 24. Sequences of these peptide ions fit within the sequence of peptide m/z 1586.64. 
The physicochemical parameters relative to the molecular identification of proteins in spots ID22 and ID24 are shown in Table 2.

\begin{tabular}{|c|c|c|c|c|c|c|c|c|c|}
\hline $\begin{array}{l}\text { D } \\
\text { के } \\
\text { के }\end{array}$ & 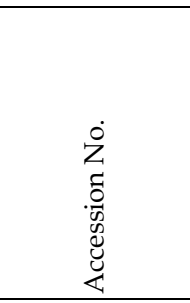 & 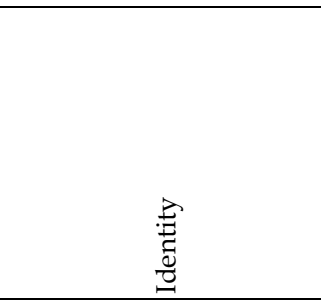 & 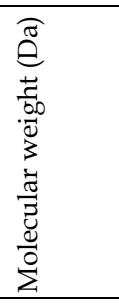 & 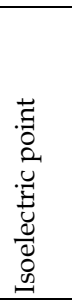 & $\begin{array}{l}\vec{\Xi} \\
0 \\
\dot{0} \\
\dot{\theta} \\
\\
\end{array}$ & 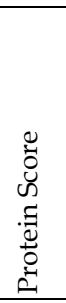 & 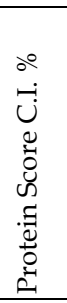 & 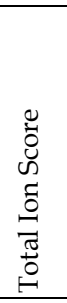 & 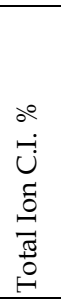 \\
\hline 22 & gi|15988119 & $\begin{array}{l}\text { Chain C, Crystal } \\
\text { Structure Of Soybean } \\
\text { Proglycinin A1aB1b } \\
\text { Homotrimer }\end{array}$ & 53590,6 & 5,78 & 12 & 198 & 100 & 89 & 100 \\
\hline 24 & gi|15988119 & $\begin{array}{l}\text { Chain C, Crystal } \\
\text { Structure Of Soybean } \\
\text { Proglycinin A1aB1b } \\
\text { Homotrimer }\end{array}$ & 53590,6 & 5,78 & 10 & 199 & 100 & 124 & 100 \\
\hline
\end{tabular}

Table 2. Chemical characterization of proteins in 2D-DIGE spots 22 and 24 from the embryonic axes of soybean subjected to thermal shock at $40^{\circ} \mathrm{C}$ for $2 \mathrm{~h}$.

The increment in the volume of spots 22 and 24 (proglycinin A1aB1b isomers) is shown in Table 3. The two protein isomers showed the highest expression under each stressing conditions tested (the exception was $\mathrm{HS} 42^{\circ} \mathrm{C} / 2 \mathrm{~h}$ ).

\begin{tabular}{|c|c|c|c|c|c|c|}
\hline $\begin{array}{l}\text { A } \\
\overrightarrow{0} \\
\text { के }\end{array}$ & 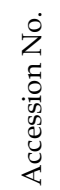 & 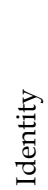 & 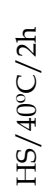 & 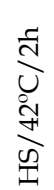 & 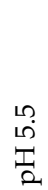 & 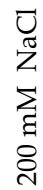 \\
\hline
\end{tabular}

\begin{tabular}{|c|c|c|c|c|c|c|}
\hline 22 & gi|15988119 & $\begin{array}{c}\text { Chain C, Crystal Structure Of } \\
\text { Soybean Proglycinin A1aB1b } \\
\text { Homotrimer }\end{array}$ & $87,07^{*}$ & 1,01 & 15,48 & 24,32 \\
\hline 24 & gi|15988119 & $\begin{array}{c}\text { Chain C, Crystal Structure Of } \\
\text { Soybean Proglycinin A1aB1b } \\
\text { Homotrimer }\end{array}$ & 78,67 & $-1,0$ & 10,07 & 12,63 \\
\hline
\end{tabular}

\footnotetext{
*Upregulation or downregulation of proteins in relation to control lot (fold times).
}

Table 3. Increment in the expression of spot proteins ID-22 and ID-24 in the embryonic axes of soybean subjected to several stressing conditions. 


\section{Peptide localization.}

Localization of peptides m/z 2667.02 (from 2D-DIGE spot ID 22) and m/z 1586.64 (from 2DDIGE spot 24) within the Chain C, crystal structure of soybean proglycinin A1aB1b homotrimer (Accession No. gi|15988119) (Adachi et al. 2001), is shown below. Peptide m/z 2667.02 goes from a. a. 79 to 101 (bold, underlined sequence) and peptide m/z 1586.64 goes from a.a. 163 to 175 (underlined sequence).

1 FSSREQPQQN ECQIQKLNALKPDNRIESEG GLIETWNPNN KPFQCAGVAL SRCTLNRNAL 61 RRPSYTNGPQ EIYIQQGK GI FGMIYPGCPS TFEEPQQPQQ RGQSSRPQDR HQKIYNFREG 121 DLIAVPTGVA WWMYNNEDTP VVAVSIIDTN SLENQLDQMP RR FYLAGNQEQEFLK YQQEQ

181 GGHQSQKGKH QQEEENEGGS ILSGFTLEFL EHAFSVDKQI AKNLQGENEG EDKGAIVTVK 241 GGLSVIKPPT DEQQQRPQEE EEEEEDEKPQ CKGKDKHCQR PRGSQSKSRR NGIDETICTM 301 RLRHNIGQTS SPDIYNPQAG SVTTATSLDF PALSWLRLSA EFGSLRKNAM FVPHYNLNAN 361 SIIYALNGRA LIQVVNCNGE RVFDGELQEG RVLIVPQNFV VAARSQSDNF EYVSFKTNDT 421 PMIGTLAGAN SLLNALPEEV IQHTFNLKSQ QARQIKNNNP FKFLVPPQES QKRAVA

\section{Discussion}

Soybean (Glycine max), as a crop of upmost nutritional and industrial importance, has been the subject of an enormous amount of research; the effect of adverse environmental conditions on soybean germination, aiming to develop resistant varieties, has been one of the most investigated aspects. As a result, many proteins have been found to be modified in their expression, and also in their function.

Heat, was probably the first stressing factor studied in plants. Key et al. in 1981 showed that when the growth temperature of soybean seedlings was shifted from $28^{\circ} \mathrm{C}$ to $40^{\circ} \mathrm{C}$ the pattern of protein synthesis changed rapidly; normal protein synthesis decreased and a new set of proteins was induced. These "new" proteins were identified as heat shock proteins or HSPs. A strong positive correlation between HSPs and the acquisition of thermal tolerance was noticed thereafter (Lin et al., 1984). From the time when these initial publications appeared, the study of heat-induced HSPs has been continuous, aiming to identify particular molecular species. The most recent investigations have made use of the proteomic technology; most HSPs have been identified as stabilizing (refolding) proteins, storage proteins or respiratory-related proteins (Ren et al., 2009).

Although HSPs are meant to prevent, and even reverse, the molecular alterations induced by heat (Boston et al., 1996), they might be inefficient in cell protection when the temperature intensity is beyond the tolerance threshold (Schöffl et al., 1999). Direct effects of heat include denaturation and aggregation of proteins, changes in the structure and function of cell membranes, including lipid fluidization, enzyme inactivation in mitochondria and chloroplasts, inhibition in the synthesis of proteins and many other alterations (Howarth, 2005). The diminution in the expression levels of 11 proteins in the lot shocked at $42^{\circ} \mathrm{C}$ in the present study (Table 1) indicated that this stressing condition overwhelmed the tolerance threshold in the soybean seeds.

The effect of salinity has also been studied in soybean. Protein changes similar to those noted in soybean subjected to thermal shock have been described in soybean subjected to 
high salinity. High salinity may lead to rapid accumulation of reactive oxygen species (ROS) in the plant tissues (Zhu, 2001). In turn, ROS may produce degradation of photosynthetic pigments, lipid peroxidation, membrane permeability alteration, protein denaturation, and DNA mutations (Mittler, 2002). Salinity leads to reduction in photosynthesis, leaf area and biomass (Kao et al., 2006). To cope with salt stress, soybean has developed several tolerance mechanisms, including maintenance of ion homeostasis; restoration of osmolite balance, and the synthesis of antioxidants (phenols) and enzymes such as superoxide dismutase and peroxidase (Gossett et al., 1994; Phang et al., 2008), among others. In addition, several metabolic proteins in soybean have been found to be down-regulated by high salinity (glyceraldehydes-3-phosphate dehydrogenase and fructokinase-2, among them) while others have been found to be up-regulated (stem $31 \mathrm{kDa}$ glycoprotein precursor, for instance) (Sobhanian et al., 2010). In our study, germination of soybean in the presence of 200 $\mathrm{mM} \mathrm{NaCl}$ led to a significant increase in the expression of 29 out of the 35 proteins over expressed in soybean shocked at $40^{\circ} \mathrm{C}$. Connection between high salinity, extreme heat, dryness, and oxidative stress, as stressing factors in plants has been recognized (Zhu, 2001).

To our knowledge, acidity as a stressing factor has not been studied, at least not in soybean; therefore, our results are pioneers in this subject. As pointed out in the Results section, acidity at $\mathrm{pH} 5.5$, induced the overexpression of 31 proteins, two of them being the same proteins over-expressed in response to the other stressing factors tested $\left(\mathrm{HS} 40^{\circ} \mathrm{C}\right.$ and $200 \mathrm{mM} \mathrm{NaCl}$ ).

The importance and novelty of the present study is that the stress response of soybean was investigated in a comparative manner, in soybean-minicrops subjected to four different stressing conditions, namely: heating at $40^{\circ} \mathrm{C}\left(\mathrm{HS} 40^{\circ} \mathrm{C} / 2 \mathrm{~h}\right)$, heating at $42^{\circ} \mathrm{C}\left(\mathrm{HS} 42^{\circ} \mathrm{C} / 2 \mathrm{~h}\right)$, acidic environment ( $\mathrm{pH} 5.5)$, and high salt concentration $(200 \mathrm{mM} \mathrm{NaCl})$.

The finding that 35 proteins out of the $\approx 2000$ proteins detected in soybean grown under normal conditions $\left(10 \mathrm{mM}\right.$ phosphate, $\left.\mathrm{pH} 7.0,28^{\circ} \mathrm{C}\right)$ showed modification in their expression, most of them at increase, was very informative. These 35 proteins behaved as heat-shock proteins under the principle that they increased (the majority) or decreased their expression in $\geq 1.5$ times in comparison with the control lot. Within those proteins that increased their expression there were two spot-proteins, ID-22 and ID-24 (by 2D-DIGE), that maximally increased under all of the stressing situations applied; the exception was $\mathrm{HS} 42^{\circ} \mathrm{C} / 2 \mathrm{~h}$ that resulted the most deleterious factor as this factor negatively affected not only the expression of proteins but also the germination of the grain. As proteins ID-22 and ID-24 maximally over expressed under the stressing factors $\mathrm{HS} 40^{\circ} \mathrm{C} / 2 \mathrm{~h}, \mathrm{pH} 5.5$, and $200 \mathrm{mM} \mathrm{NaCl}$, we thought of these two proteins as vital elements for the growing of soybean exposed to all kinds of adverse environments. Therefore, these proteins deserved further analysis and on this base we decided to analyze the nature of these proteins by MALDI TOF and MALDI TOF/TOF. The analysis of peptides allowed us to identify the two proteins as isomers of the glycinin in its immature form, pro-glycinin. Seed proteins are usually synthesized as precursors having a leader prepeptide sequence that contains the signal for transport, processing and targeting from the site of synthesis to the storage organelles. The signal sequence is involved in directing the nascent chain from the rough side of the endoplasmic reticulum (ER) to the ER lumen. After cotranslational cleavage of the signal peptide, the polypeptides are subjected to glycosylation and/or to folding through enzyme-catalyzed disulfide formation. Then, mature polypeptides are directed to storage protein bodies with the help of chaperones. Close to $90 \%$ of the proteins in soybean exist as storage proteins, which mostly consist of $\beta$-conglycinin (7S) and glycinin (11S). Glycinin, the protein found maximally up-regulated under all stressing situations tested in this study, is a 300-380 kDa hexamer (Peng et al, 1984; Utsumi, 1992); each 
subunit is composed of acidic $(\sim 35 \mathrm{kDa})$ and basic $(\sim 20 \mathrm{kDa})$ polypeptides linked together by a disulfide bond. Five subunits have been identified and classified within group I: A1aB1b (53.6 $\mathrm{kDa})$, A2B1a (52.4 kDa) and A1bB2 (52.2 kDa), or within group II: A5A4B3 (61.2 kDa) and A3B4 (55.4 kDa) (Maruyama et al, 2006). Glycinin subunits are polymorphic (i.e., there are some amino acid replacements in the same kind of subunit among different soybean cultivars). In addition, glycinin exhibits molecular heterogeneity, because the molecule is a hexamer with different subunit composition. Glycinin hexamers dissociate to their constituent polypeptide subunits, depending upon $\mathrm{pH}$, ionic strength, and heating temperature (Adachi et al., 2001, 2003). The reason for the impressive over-expression of glycinin when soybean is subjected to heat, acidity or salinity (this study) is not yet understood. However, because this protein shows chaperone activity (Choi et al., 2004), it is possible that acting as a finely tuned sensor of stress, glycinin $\mathrm{A} 1 \mathrm{aB} 1 \mathrm{~b}$ is efficiently up-regulated to cope with the adverse effects of environmental stressants in general, including heat, salinity and acidity (see text), waterlogging (Alam et al, 2010), Chilling (Cheng et al, 2010, and radioactivity (Danchenko et al, 2009). Reports on other proteins with hexameric structure and chaperone activity, reinforce this idea (Sauer et al., 2004; Lee et al, 2010).

\section{Acknowledgments}

Full support for this study came from Instituto Politécnico Nacional, through SIP (Secretaría de Investigación y Posgrado Projects 20090424 and 20100533) and COFAA (Comisión de Operación y Fomento de las Actividades Académicas). P.A.P. received financial support from COTEPABE/IPN; R.M.O., J.P.L.-A., G.M.H. and O.R.E., are fellow holders of CONACyT (SNI), México. The services of Applied Biomics Inc (Hayward, CA, USA) were used to complete the proteomic analysis of the samples tested in this study.

\section{References}

[1] Adachi M, Takenaka Y, Gidamis AB, Mikami B, Utsumi S. 2001. Crystal structure of soybean proglycinin A1aB1b homotrimer. J Mol Biol. 305, 291-305.

[2] Adachi M, Kanamori J, Masuda T, et al. 2003. Crystal structure of soybean 11S globulin: glycinin A3B4 homohexamer. Proc Natl Acad Sci (USA) 100, 7395-7400.

[3] Aghaei K, Ehsanpour AA, Shah AH, Komatsu S. 2009. Proteome analysis of soybean hypocotil and root under salt stress. Amino Acids 36, 91-98.

[4] Alam I, Lee D-G, Kim K-H., et al. 2010. Proteome analysis of soybean roots under waterlogging stress at an early vegetative stage. J. Biosci. 35, 49-62.

[5] Arce-Paredes P, Mora-Escobedo E, Cid-Gutierrez JL, Rojas-Espinosa O. 2009. Characterization of four soybean varieties grown on Mexican land. A preliminary analysis for a proteomic study. Arch Agro Soil Sci. 56, 139-148.

[6] Boston RS, Viitanen PV, Vierling E. 1996. Molecular chaperones and protein folding in plants. Plant Mol Biol. 32, 191-222.

[7] Cheng L, Gao X, Li S, et al. 2010. Proteomic analysis of soybean [Glycine max (L) Meer.] seeds during inhibition at chilling temperature. Mol Breeding 26, 1-17.

[8] Choi SK, Adachi M, Yoshikawa M et al. 2004. Soybean glycinin A1aB1b subunit has a molecular chaperone-like function to assist folding of the other subunit having low folding ability. Biosci Biotechnol Biochem. 68, 1991-1994. 
[9] Danchenko M, Skultely L, Rashydov NM, et al. 2009. Proteomic analysis of mature soybean seeds from Chernobyl area suggests plant adaptation to the contaminated environment. J Proteom Res. 8, 2915-2922.

[10] De Maio A. 1999. Heat shock proteins: facts, thoughts, and dreams. Shock 11, 1-12.

[11] Feder ME, Hofmann GE. 1999. Heat-shock proteins, molecular chaperones and the stress response: evolutionary and ecological physiology. Annu Rev Physiol. 61, 243-82.

[12] Gossett DR, Millhollon EP, Lucas MC. 1994. Changes in antioxidant levels in response to $\mathrm{NaCl}$ treatment in salt tolerant and sensitive cultivars of cotton, Gossypium hirsutum, L. Crop Sci. 34, 706-714.

[13] Howarth CJ. 2005. Genetic improvements of tolerance to high temperature. In: Abiotic stresses plant resistance through breeding and molecular approaches. Ashraf M, Harris PJC, editors. Food Products Press. The Haworth Press, Inc. New-York. pp 277-300.

[14] Hsieh MH, Chen JT, Jinn TL, Chen YM, Lin CY. 1992. A class of soybean low molecular weight heat shock proteins: immunological study and quantization. Plant Physiol. 99, 1279-1284.

[15] Kao W-Y, Tsai T-T, Tsai H-G, Shih C-N. 2006. Response of three Glycine species to salt stress. Envir Exper Botany 56, 120-125.

[16] Key JL, C-Y Ling, Y-M Chen. 1981. Heat shock proteins of higher plants. Proc Nat Acad Sci (USA) 78, 3526-3530.

[17] Lee S, Sielaff B, Lee J, Tsai FTF. 2010. CryoEM structure of HSP104 and its mechanistic implication for protein disaggregation. Proc Natl Acad Sci (USA). Early edition, pp $1-6$.

[18] Li Z, Srivastava P. 2004. Heat-shock proteins. Curr Protoc Immunol. Appendix 1T. Review

[19] Lin C-Y, Roberts JK, Key JL. 1984. Acquisition of thermotolerance in soybean seedlings. Plant Physiol. 74, 152-160.

[20] Lowry OH, Rosebrough NJ, Farr AK, Randall RJ. 1951. Protein measurement with the Folin phenol reagent. J Biol Chem. 193, 265-269.

[21] Macario AJ, Conway de Macario E. 2007. Molecular chaperones: multiple function, pathologies, and potential applications. Front Biosci. 12, 2588-2600.

[22] Mahajan S, Tuteja N. 2005. Cold, salinity, and drought stresses; an overview. Arch Biochem Biophys. 444, 139-158.

[23] Mansfield MA, Key JL. 1987. Synthesis of the low molecular weight heat shock proteins in plants. Plant Physiol. 84, 1007-1017.

[24] Maruyama N, Mun LC, Tatsuhara M, et al. 2006. Multiple vacuolar sorting determinants exist in soybean $11 S$ globulin. The Plant Cell 18, 1253-1273.

[25] Mittler R. 2002. Oxidative stress, antioxidants and stress tolerance. Trends Plant Sci. 7, 405-410.

[26] Nagesh-Babu R, Devaraj VR. 2008. High temperature and salt stress response in French bean (Phaseolus vulgaris). Austr J Crop Sci. 22, 40-48.

[27] Nieto-Sotelo J, Martínez LM, Ponce G, et al. 2002. Maize HSP101 plays important roles in both induced and basal thermotolerance and primary root growth. Plant Cell. 14, 1621-1633.

[28] Ortíz CA, Bravo LA, Pinto M, Cardemil L. 1995. Physiological and molecular responses of Prosopis chilensis under field and simulation conditions. Phytochemistry 40, 1375-1382.

[29] Ortíz CA, Cardemil L. 2001. Heat-shock responses in two leguminous plants: a comparative study. J Exp Bot. 52, 1711-1719. 
[30] Ougham HJ, Stoddart JL. 1986. Synthesis of heat-shock protein and acquisition of thermotolerance in high-temperature tolerant and high-temperature susceptible lines of Sorghum. Plant Science 44, 163-167.

[31] Pareek A, Singla SL, Grover A. 1995. Immunological evidence for accumulation of two high-molecular-weight (104 and $90 \mathrm{kDa}$ ) HSPs in response to different stresses in rice and in response to high temperature stress in diverse plant genera. Plant Mol Biol. 2, 293-301.

[32] Peng JC, Quass DW, Dayton WR, Allen CE. 1984. The physicochemical and functional properties of soybean $11 S$ globulin-A review. Cereal Chem. 61, 480-490.

[33] Phang T-H, Shao G, Lam H-M. 2008. Salt tolerance in soybean. J Integr Plant Biol. 50, 1196-1212.

[34] Polenta GA, Calvete JJ, González CB. 2007. Isolation and characterization of the main small heat shock proteins induced in tomato pericarp by thermal treatment. FEBS J. 274, 6447-6455.

[35] Queitsch C, Hong SW, Vierling E, Lindquist S. 2000. Heat shock protein 101 plays a crucial role in thermotolerance in Arabidopsis. Plant Cell 12, 479-492.

[36] Ren C, Bilyeu KD, Beuselinck PR. 2009. Composition, Vigor, and Proteome of mature soybean seeds developed under high temperature. Crop Sci. 40, 1010-1022.

[37] Ritossa FA. 1962. New puffing pattern induced by heat shock and DNP in Drosophila. Experientia. 18, 571-573.

[38] Sancho AI, Gillabert M, Tapp H, et al. 2008. Effect of environmental stress during grain filling on the soluble proteome of wheat (Triticum aestivum) dough liquor. J Agric Food Chem. 56, 5386-5393.

[39] Santoro MG. 2000. Heat Shock factors and the control of the stress response. Biochem Pharmacol. 59, 55-63.

[40] Sauer R, Bolon T, Sauer RT, et al. 2004. Sculpting the proteome with AAA $(+)$ proteases and disassembly machines. Cell 119, 9-18.

[41] Schlesinger MJ. 1990. Heat shock proteins. J Biol Chem. 265, 12111-12114.

[42] Schlesinger MJ. 1994. How cells cope with stress and the function of heat shock proteins. Pediatr Res. 36, 1-6.

[43] Schöffl F, Prandl R, Reindl A. 1999. Molecular responses to heat stress. In: Shinozaki K, Yamaguchi-Shinozaki K, editors. Molecular responses to cold, drought, heat and salt stress in higher plants. R. G. Landes Co. Austin, Texas. pp. 81-98.

[44] Sobhanian H, Razavizadeh R, Nanjo Y. et al. 2010. Proteome analysis of soybean leaves, hypocotyls and roots under salt stress. Proteome Science 8, 19-33.

[45] Tonsor SJ, Scott C, Boumaza I, et al. 2008. Heat shock protein 101 effects in A. thaliana: genetic variation, fitness and pleiotropy in controlled temperature conditions. Mol Ecol. 17, 1614-1626.

[46] Utsumi S. 1992. Plant food protein engineering. Adv Food Nutr Res. 36, 89-208.

[47] Wang W. Vinocur B. Altman A. 2003. Plant responses to drought, salinity and extreme temperatures; towards genetic engineering for stress tolerance. Planta. 218, 1-14.

[48] Wu C. 1995. Heat shock transcription factors: structure and regulation. Annu Rev Cell Dev Biol. 11, 441-69.

[49] Zhu JK. 2001. Plant salt tolerance. Trends Plant Sci. 6, 66-71. 


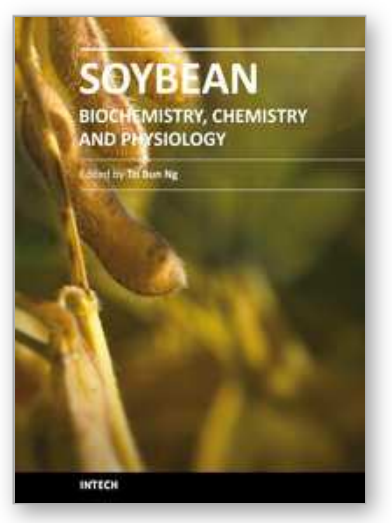

\section{Soybean - Biochemistry, Chemistry and Physiology \\ Edited by Prof. Tzi-Bun Ng}

ISBN 978-953-307-219-7

Hard cover, 642 pages

Publisher InTech

Published online 26, April, 2011

Published in print edition April, 2011

Soybean is an agricultural crop of tremendous economic importance. Soybean and food items derived from it form dietary components of numerous people, especially those living in the Orient. The health benefits of soybean have attracted the attention of nutritionists as well as common people.

\section{How to reference}

In order to correctly reference this scholarly work, feel free to copy and paste the following:

Patricia Arce-Paredes, Rosalva Mora-Escobedo, Juan Pedro Luna-Arias, Guillermo Mendoza-Hernández and Oscar Rojas-Espinosa (2011). Heat, Salinity, and Acidity, Commonly Upregulate A1aB1b Proglycinin in Soybean Embryonic Axes, Soybean - Biochemistry, Chemistry and Physiology, Prof. Tzi-Bun Ng (Ed.), ISBN: 978-953-307-219-7, InTech, Available from: http://www.intechopen.com/books/soybean-biochemistrychemistry-and-physiology/heat-salinity-and-acidity-commonly-upregulate-a1ab1b-proglycinin-in-soybeanembryonic-axes

\section{INTECH}

open science | open minds

\section{InTech Europe}

University Campus STeP Ri

Slavka Krautzeka 83/A

51000 Rijeka, Croatia

Phone: +385 (51) 770447

Fax: +385 (51) 686166

www.intechopen.com

\section{InTech China}

Unit 405, Office Block, Hotel Equatorial Shanghai

No.65, Yan An Road (West), Shanghai, 200040, China

中国上海市延安西路65号上海国际贵都大饭店办公楼 405 单元

Phone: +86-21-62489820

Fax: +86-21-62489821 
(C) 2011 The Author(s). Licensee IntechOpen. This chapter is distributed under the terms of the Creative Commons Attribution-NonCommercialShareAlike-3.0 License, which permits use, distribution and reproduction for non-commercial purposes, provided the original is properly cited and derivative works building on this content are distributed under the same license. 